REVIEW ARTICLE

\title{
Lyme borreliosis: insights into tick- / host-borrelia relations
}

\author{
Libor Grubhoffer ${ }^{1}$, Maryna Golovchenko ${ }^{1}$, Marie Vancová ${ }^{1}$, Klára Zacharovová-Slavíčková ${ }^{1}$, Nataliia \\ Rudenko ${ }^{1}$ and James H. Oliver, Jr. ${ }^{2}$ \\ ${ }^{1}$ Institute of Parasitology, Academy of Sciences of the Czech Republic and Faculty of Biological Sciences, University of South \\ Bohemia, Branišovská 31, 37005 České Budějovice, Czech Republic; \\ ${ }^{2}$ Institute of Arthropodology and Parasitology, Georgia Southern University, Statesboro, Georgia 30460-8056, USA
}

Key words: borrelia spirochete, Lyme borreliosis, ticks, vectors, interactions, glycoproteins

\begin{abstract}
Lyme borreliosis (LB) is a serious infectious disease of humans and some domestic animals in temperate regions of the Northern Hemisphere. It is caused by certain spirochetes in the Borrelia burgdorferi sensu lato (s.1.) species complex. The complex consists of 11 species (genospecies). Borrelia burgdorferi sensu stricto (s.s.), Borrelia garinii and Borrelia afzelii are the major agents of human disease. Borrelia burgdorferi s.l. species are transmitted mainly by ticks belonging to the Ixodes ricinus species complex plus a few additional species not currently assigned to the complex. B. burgdorferi infections may produce an acute or chronic disease with a wide array of clinical symptoms such as erythema migrans (EM), carditis, arthritis, neuroborreliosis, and acrodermatitis chronica atrophicans (ACA). Differences in LB spirochetes 'genospecies' and strains/isolates determine the occurrence and severity of this multi-system disease. Accurate and reliable identification of the LB spirochetes in ticks as well as knowledge of their prevalence are essential for prevention against the disease and development of an effective vaccine. An overview of the knowledge of molecular factors with emphasis on potential protein-carbohydrate interactions in the tickborrelia system is the main focus of this review.
\end{abstract}

\section{BORRELIA BURGDORFERI SENSU LATO AS THE CAUSATIVE AGENT OF LYME BORRELIOSIS}

Lyme borreliosis (LB) is a disease of epidemiological, clinical and social importance, especially in Europe, USA and Asia (Stanek 1997, Burgdorfer 2001, Takada et al. 2001, Weber 2001, Dennis and Hayes 2002, Kamradt 2002, Hengge et al. 2003).

\subsection{Genospecies of Borrelia burgdorferi sensu lato}

LB is caused by infection with certain spirochetes assigned to the Borrelia burgdorferi sensu lato (s.l.) species complex. Much attention has been paid to the basic biological and ecological aspects of the LB causative agent including the molecular mechanisms of pathogenesis with the aim to understand the mechanism of interaction between borrelia spirochetes, their arthropod vectors (ticks) and their vertebrate hosts. In the autumn of 1981, a new species of the genus Borrelia, a spirochete described as Borrelia burgdorferi, was first identified by W. Burgdorfer from the hard tick Ixodes scapularis (formerly called Ixodes dammini) (Burgdorfer et al. 1982, Oliver et al. 1993). Borrelia burgdorferi was originally characterized as a single species (Johnson et al. 1984). However, in recent years it has become clear that $B$. burgdorferi is composed of a number of distinct species and genomic groups. Thus the term "Borrelia burgdorferi sensu lato" is now used to collectively refer to all Borrelia isolates within this species complex. To date, a lot is known about the species composition of the whole complex of which three (perhaps four) species cause the disease with clinical symptoms typical of LB in different parts of the world. Based on gene sequence variation of a limited numbers of loci, the following 11 genospecies of $B$. burgdorferi sensu lato have so far been discriminated from each other and named: $B$. burgdorferi sensu stricto, B. garinii and $B$. afzelii (Baranton et al. 1992, Canica et al. 1993), B. japonica (Kawabata et al. 1993), B. andersonii (Marconi et al. 1995), B. tanukii, B. turdi (Fukunaga et al. 1996), B. lusitaniae (LeFleche et al. 1997), Borrelia bissettii (formerly genomic group DN127) (Postic et al. 1998), B. valaisiana (Wang et al. 1999), and the recently described B. sinica (Masuzawa et al. 2001). Borrelia bissettii has been cultured from patients as an undocumented strain that is genetically similar to Borrelia japonica, but appears only occasionally in humans. The differences between species are observed in the different antigen composition and in the substitution of the structural components and their functional activities. There are differences in the antigen profile between various species of LB spirochetes that are specifically revealed in the molecular interactions of pathogen with molecular factors (receptors) of tick or host inner environment. Due to the above-mentioned molecular differences significant diversities exist in the LB clinical picture (Assous et al. 1993, van Dam et al. 1993). Prevalence rates of $B$. burgdorferi sensu lato in host-seeking 
Ixodes ricinus ticks in Europe were estimated by Hubálek and Halouzka (1998). The results obtained with adult ticks varied according to the method used (cultivation on BSK medium: 11\%; PCR: 29\%; microscopic techniques: $17-20 \%$ ).

\subsection{Biogeography of $L B$ spirochetes}

In Eurasia, seven genospecies of B. burgdorferi s.l. have been recorded, three of which, i.e. $B$. burgdorferi s.s., B. garinii, and B. afzelii, have been cultured from patients and traditionally are thought to be responsible for human Lyme borreliosis (Van Dam et al. 1993). However, an additional genospecies, B. bissettii was also reported from patients in Slovenia. The nine isolates were closely related to the North American isolate 25015 , a member of the $B$. bissettii group. Thus, strains belonging to $B$. bissettii may also cause human disease (Picken et al. 1996, Strle et al. 1997). In 1992, one more isolate, A14S, was cultured from a skin biopsy specimen of a Dutch patient with erythema migrans who had contracted the disease in the Netherlands. That isolate could not be determined using various monoclonal antibodies (MAbs) against B. burgdorferi s.l. Moreover, it showed a unique pattern upon ribotyping analysis that differentiated it from B. burgdorferi s.S., B. garinii and $B$. afzelii. In addition, a striking genetic difference between this isolate and 135 other LB-related Borrelia isolates was noted in the randomly amplified polymorphic DNA (RAPD) fingerprinting analysis (van Dam et al. 1993). Isolate A14S also clearly differs from B. bissettii, the fourth genomic group reported to be able to cause human LB. Therefore, this isolate (A14S) most likely represents a new Borrelia genomic group, recently named B. spielmani (Richter et al. 2004), which is the fifth group with culture-confirmed pathogenic potential for causing human LB besides $B$. burgdorferi s.s., B. garinii, B. afzelii and B. bissettii (Wang et al. 1999). However, it also appeared that $B$. valaisiana may be pathogenic for humans, since one serum sample from a patient with Lyme arthritis was more reactive by immunoblotting to this species (Ryffel et al. 1999). Moreover, DNA specific for this species was detected by PCR in skin biopsies of patients with erythema migrans and acrodermatitis chronica atrophicans (Rijpkema et al. 1997). Seven other B. burgdorferi sensu lato species B. japonica, B. andersonii, B. turdi, B. tanukii, B. bissettii, $B$. sinica, and $B$. lusitaniae - were isolated from tick species in the United States (B. andersonii and B. bissettii); Japan (B. japonica, B. turdi and B. tanukii); China (B. sinica); and Portugal, Czech Republic, Slovakia, Byelorussia, and North Africa (B. lusitaniae). They are considered nonpathogenic for humans (Kawabata et al. 1993, Fukunaga et al. 1995, Marconi et al. 1995, LeFleche et al. 1997, Postic et al. 1998, Gern et al. 1999, Masuzawa 2004). Nevertheless, a recent study has pointed out that a low passage of $B$. lusitaniae (strain PotiB2) is able to induce disease in susceptible mice
(Zeidner et al. 2001). B. lusitaniae has been isolated from a patient in Portugal (Collares-Pereira et al. 2004).

Recently, an unknown Borrelia species from South Bohemia in the Czech Republic was detected in Ixodes ricinus ticks in the area around České Budějovice. Using the techniques of spacer and nested PCR followed by RFLP analysis (with MseI restriction endonuclease), its similarity to Borrelia japonica was proved (Rudenko and Obbels, unpublished). Subsequently, Derdáková et al. (2003) confirmed this borrelia as identical with A14S (van Dam et al. 1993) as well as with that Borrelia which they isolated from Ixodes ricinus in East Slovakia and labeled as I-77.

Qiu et al. (2004) carried out a comparative genomic analysis of closely related borrelia isolates and concluded that $B$. burgdorferi undergoes genome-wide genetic exchanges including plasmid transfers. Frequent recombination implies a potential for rapid adaptive evolution and a possible polygenic basis of B. burgdorferi pathogenicity.

\subsection{Clinical manifestations of $L B$ and differences in borrelia pathogenicity}

Different Borrelia species have been associated with distinct clinical manifestations of LB. Erythema migrans is one of symptoms that is common for LB patients infected by different species. Retrospective analysis revealed that many clinical symptoms of LB had been separately recorded by European clinicians since the end of the 19th century (Weber and Pfister 1993). It appears that there is an association of $B$. garinii with neurological symptoms, an association of $B$. burgdorferi s.s. with arthritis, and an association of $B$. afzelii with acrodermatitis chronica atrophicans (Demaerschalck et al. 1995). Nevertheless, although each of the genospecies may cause the symptoms associated with them above, a particular genospecies may cause any of the symptoms listed plus others. As a result of its clinical manifestations, LB was described as the new "great imitator" of various human diseases (Pachner 1989).

LB spirochetes are highly heterogeneous, as is readily apparent upon analysis of their antigenic composition, plasmid content or genomic restriction pattern (Livey et al. 1995). The revealed structural and functional diversity has required classification of these spirochetes into species (genospecies) and genomic groups. However, even within these taxonomic groupings there may be extensive strain differences and different antigenic or plasmid profiles even from single isolates. Those isolates may alter during in vitro (Livey et al. 1995) and in vivo (Persing et al. 1994) passaging and this may be accompanied by the loss of virulence (Livey et al. 1995).

In the past several years, various molecular approaches have been developed and successfully used for the identification and typing of the LB-related spirochetes (Tenover et al. 1995). Application of molecular typing methods to the classification of B. burgdorferi s.l. 
provides the framework for the systematic approach to characterisation of differences in infectivity as well as in pathogenicity between strains. Sensitive molecular typing techniques do not require large amounts of material or cultivation of spirochetes and thus will play an increasingly important role in elucidation of the pathogenic potential of different $B$. burgdorferi genotypes (Elias et al. 2002, Qiu et al. 2002, Schwan and Piesman 2002). Ultimately, the development of suitable animal models for the investigation of tissue tropisms of different B. burgdorferi s.l. species will provide a more direct evidence for the correlation between Borrelia species and clinical symptoms of LB (Ružić-Sabljić et al. 2001).

\subsection{Structure and genome of Borrelia burgdorferi sensu lato}

Analysis of genetic diversity among individual Borrelia isolates has defined a closely related cluster containing at least 11 tick-borne species of LB agents, called Borrelia burgdorferi s.l. They resemble most other spirochetes in that they are highly specialised, motile, two-membrane, spiral-shaped gram-negative bacteria that live as extracellular pathogens. Like other spirochetes, B. burgdorferi has periplasmic flagella (7 to 11 in number) that are inserted at each end of the cell and extend towards the middle of the cell body. The unique flagella allow the organism to move through viscous solutions, an ability that is presumed to be important in its migration to distant tissues following deposition in the skin layer. The length of spirochete varies between 10 and $30 \mu \mathrm{m}$ and the width from 0.2 to $0.5 \mu \mathrm{m}$. Borrelia spirochetes are fastidious and difficult to culture in vitro, requiring a specially enriched medium and low oxygen tension (Barbour and Hayes 1986).

One of the most striking features of B. burgdorferi is its unusual genome consisting of a linear chromosome of 910,724 bp and 21-27 linear (lp) and circular (cp) plasmids containing over 610,694 bp and also known as micro-chromosomes. The linear chromosome contains 853 predicted genes, of which 500 (59\%) have predicted functions based on amino acid sequence similarity with orthologous gene products. Twelve percent of the open reading frames (ORFs) matched hypothetical coding sequences of unknown functions from other organisms, and $29 \%$ were unknown genes. An average $\mathrm{G}+\mathrm{C}$ content of the chromosome is $28.6 \%$, predicted coding regions have an average size of $992 \mathrm{bp}$ (similar to that observed in other prokaryotic genomes), and an average relative molecular mass of the chromosome-encoded proteins is $37,529 \mathrm{Da}$ (ranging from 3,369 to 254,242 $\mathrm{Da})$. The median isoelectric point ( $\mathrm{pI}$ ) for all predicted proteins is 9.7 (Fraser et al. 1997).

Comparison of the plasmid profiles of LB spirochetes demonstrates that a high degree of heterogeneity and plasticity exists in terms of plasmid contents. Analysis of the nucleotide sequences (Southern analysis) indicates that the spirochete contains the following linear plasmids: lp56, lp54, lp38, 1p36, 1p28-1, lp28-2, 1p28-3, lp28-4, lp25, lp21, lp17, lp5 and the following circular plasmids: cp32-1, cp32-3, cp32-4, cp32-6, cp32-7, cp32-8, cp32-9, cp26 and cp9 (Fraser et al. 1997, Purser and Norris 2000). Considerable evidence indicates that B. burgdorferi plasmids are important in pathogenesis and that there is a relationship between plasmid content and infectivity of spirochetes. In vitro passage of $B$. burgdorferi is associated with the loss of plasmids (Barbour 1988). Plasmid loss after 10-17 passages is also coupled with decreased infectivity in mice and changes in spirochete protein expression. The results of the first step of identification of infectivity-associated plasmids indicate that $1 \mathrm{p} 25$ and $1 \mathrm{p} 28-1$ appear to be important in the spirochete pathogenesis (Purser and Norris 2000, for review see Qiu et al. 2004). At the same time, some studies indicate that genetic changes other than plasmid loss may contribute to loss of infectivity. Recent improvements in the methods for genetic manipulation should facilitate the identification of potential virulence factors and understanding the molecular basis of pathogenicity. The genes encoding virulence factors have been identified in several bacterial pathogens. These include toxins (Guignot et al. 1997, Oyston et al. 1998), capsule components (Welkos 1991, Friedlander et al. 1995), adhesins (Guo et al. 1995, Rudel et al. 1995) and invasion factors (Coleman et al. 1999, Seinost et al. 1999). Several genes potentially important during host adaptation, dissemination, infection and persistence of spirochetes are localised on plasmids. An increased understanding of the putative virulence factors and identification of new virulence-associated genes are necessary to elucidate the mechanism of pathogenesis of infection by LB spirochetes.

\subsection{Antigens of $L B$ spirochetes}

Currently, much data are available about antigenic structures of LB spirochetes, in particular about the outer membrane surface proteins (Osp) or about the components of flagella (for review see Bergström et al. 2002). The majority of these data contains the basic structural features such as their molecular weights, antigenicity, etc. After the entire genomic sequence of the LB spirochete was published (Fraser et al. 1997), localisation of genes encoding some of the given proteins was determined. Based on interaction with the antibodies of specific patient sera, expression of antigenic determinants of LB spirochetes during the infection process was determined. Little is known, however, about the functional activities of the structural units on the borrelia surface. The genome of LB spirochetes codes for a large number of lipoproteins, many of which are localised on the outer membrane and likely play a role in transmission. They are obviously expressed only at certain stages of the spirochete life cycle (de Silva and Fikrig 1997). The most studied are the outer membrane surface lipoproteins characterized as OspA (31 kDa) and OspC (21-25 kDa) (for review see Stanek 1997 and 
Bergström et al. 2002). Even their crystal structures with respect to epitopes involved in an immune response of the vertebrate host were published ( $\mathrm{Li}$ et al. 1997, Kumaran et al. 2001). The genes encoding OspA and OspB are located on the linear plasmid lp54, whereas the gene encoding OspC is located on the circular plasmid cp26. The $\operatorname{sspC}$ gene is highly variable within each species of the LB spirochetes and can be used to define groups of related clones (Baranton et al. 2001, Lin et al. 2002). The expression pattern of OspA and $\mathrm{OspC}$ is suggestive of their roles in the infection cycle of the spirochetes (Schwan et al. 1995, Pal et al. 2000, 2004a, Baranton et al. 2001, Grimm et al. 2004).

In unfed ticks, spirochetes express OspA, but not OspC. However, when the tick starts feeding on mammals, OspC synthesis is induced and OspA is repressed. Other surface antigens of B. burgdorferi are lipoprotein OspD $(28 \mathrm{kDa}$, the encoding gene localised on the linear plasmid lp38), lipoproteins OspE and OspF (19 kDa and $26 \mathrm{kDa}$, the encoding genes localised on the circular plasmid cp32, and linear plasmid $1 p 36$, respectively) and protein p27 (linear plasmid lp54). These proteins were identified as structural units of the borrelia outer membrane with the different level of expression in the separate isolates that also depend upon the phase of the life cycle of the LB spirochetes (Fig. 1). Currently, there are more structural proteins of the LB spirochetes which are under investigation. Erp (OspEF-related) proteins are surface exposed lipoproteins that are also synthesized during the initial stages of mammalian infection (Babb et al. 2001). At least some Erp proteins can bind anticomplement factor H (Hellwage et al. 2001). Kurtenbach et al. (2002) have shown a key role of the host complement to the LB spirochete diversity (see 11 genospecies of the LB spirochetes). The ability of the LB spirochetes to maintain chronic infection indicates that they are capable of immune response escape. OspE and VlsE (relapsing fever spirochete "Variable major protein" [Vmp]-like sequence E) are two outer membrane proteins highly polymorphic which might be responsible for immune evasion (McDowell et al. 2001). Two other surface lipoproteins, DbpA/DbpB (decorinbinding proteins) with molecular sizes of 20 and 22 $\mathrm{kDa}$, were identified as receptors for decorin. Decorin is a proteoglycan from the flagella surface of intestinal collagen (Feng et al. 1998,

Hagman et al. 1998). These proteins facilitate the adherence of B. burgdorferi to extracellular matrix when the spirochete invades mammalian tissue (Ulbrandt et al. 2001). Probert et al. (2001) described the fibronectinbinding protein BBK32 (47 kDa), which is localised on the outer surface of the LB spirochetes. The outer membrane protein P66 was suggested as a candidate ligand for recognition of the integrin alpha(IIb)beta(3) which takes place in attachment of the spirochetes to the host cells (Baranton et al. 1998, Defoe and Coburn 2001). In addition, membrane-associated protein P66 contains a domain homologous to the L-sialyl motif which is a highly conservative region of the sequence in (poly) sialyltransferases (www.ncbi.blm.nih.gov/blast/). Sialyltransferases made a large family of proteins which are diverse in their functional activities; some are even lacking the enzyme activity, and therefore they can retain the carbohydrate-binding (lectin or lectin-like) activity.

The role of certain proteases during LB spirochete invasion and pathogenesis is essential. Discovery of the LB spirochete receptor for plasminogen was of particular interest. After activation in plasmin, the receptor facilitates dissemination of the spirochetes inside the tick as well as strengthens the spirochetaemia in the host organism (Fuchs et al. 1994, Coleman et al. 1997). Based on results of the receptor analysis, Fuchs et al. (1994) concluded that the above-mentioned receptor is the surface lipoprotein OspA. Recently discovered sialoglycoprotease (gcp, BB0769) might be involved in borrelia invasion (Fraser et al. 1997). Till now there is nothing known about the function of this protease. It can be suggested that sialylated glycoproteins in host tissues might be target receptors for the LB spirochetes.

It has been known for several years that $B$. burgdorferi binds to many types of mammalian cells and to extracellular matrix (Szczepanski et al. 1990). GarciaMonco et al. (1992) reported that host cell galactosylcerebroside is recognized by B. burgdorferi, and Isaacs (1994) proved that borrelia spirochetes are bound to the host cell proteoglycans. However, OspA and OspB were removed from the group of expected antigenic structures that could be directly responsible for the adhesion of borrelia (Garcia-Monco et al. 1992, Isaacs 1994). According to Leong et al. (1995), haemagglutination activity of the LB spirochetes is not mediated by any of the above-mentioned molecules. They presented evidence that the LB spirochetes provide a lectin activity that promotes agglutination of erythrocytes and bacteria attachment to the target glycosaminoglycans.

Regarding membrane systems of the LB spirochetes, B. burgdorferi s.l. spirochetes contain both an outer membrane with most of above-mentioned molecules/ antigens, and a cytoplasmic membrane analogous to the surface of enteric gram-negative bacteria. In contrast to an extraordinary abundance of lipoproteins in the outer membrane, there are just a few transmembranespanning proteins known in the cytoplasmic membrane of the LB spirochetes. An integral peptide P13 is one of those (Noppa et al. 2001).

\subsection{Glycoproteins and other glycoconjugates in LB spirochetes}

Bacterial lipopolysaccharides and peptidoglycans used to be the only molecules considered as bacterial glycoconjugates. Recently, structural analyses of glycolipids of $B$. burgdorferi have identified two surface-exposed glycolipids BbGL-II ( $\alpha$-galactosyl-diacyl-glycerolipid) and BbGL-I (cholesteryl 6-O-acyl- $\beta$-D-galactopyranoside). It was demonstrated that $B$. burgdorferi 

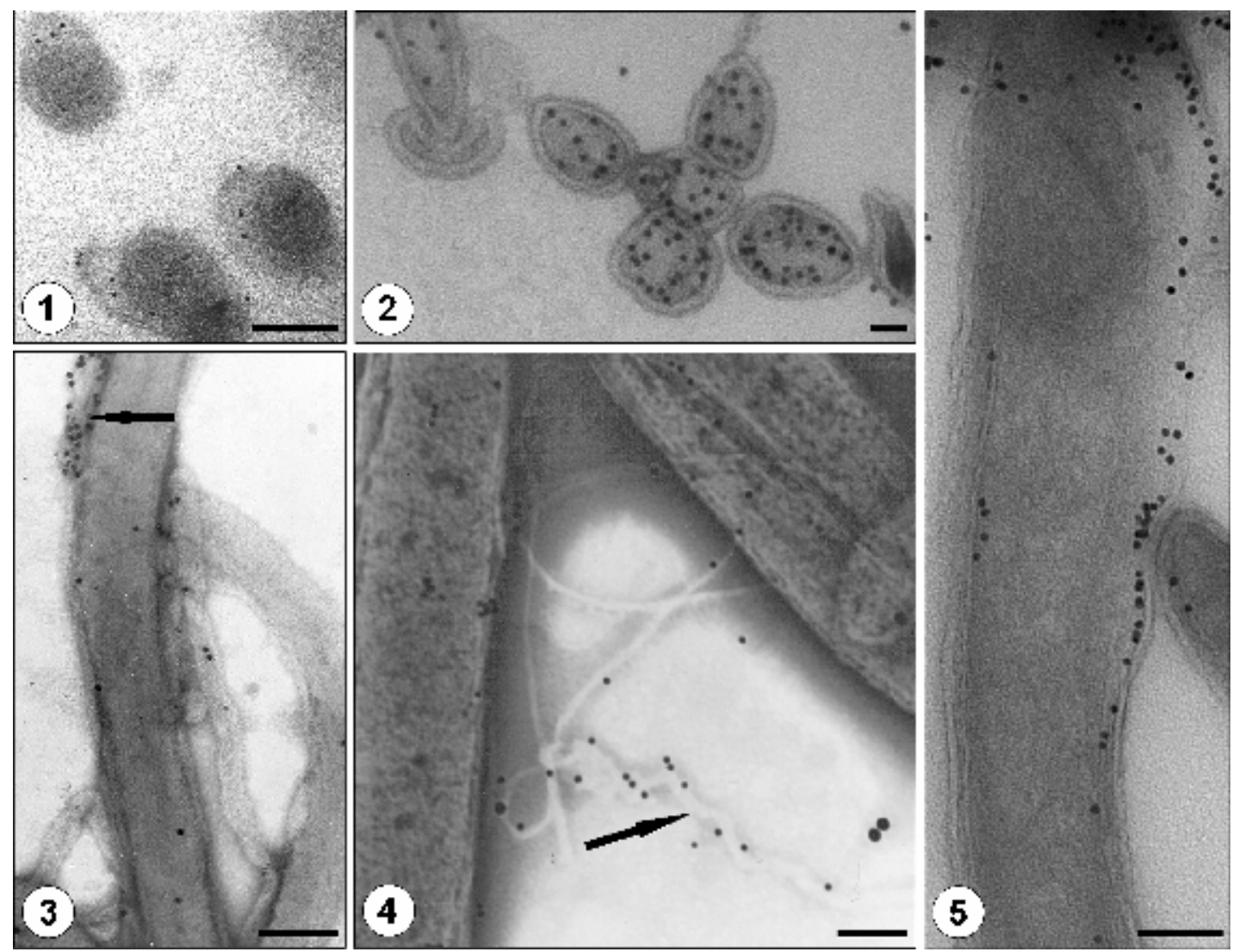

Figs. 1-5. Transmission electron micrographs of cultured Lyme borreliosis spirochetes. Fig. 1. A cryosection of Borrelia burgdorferi B31 labeled with anti-OspA antibodies followed by Protein A-gold detection. Fig. 2. Cryosectioned outer membrane vesicles of $B$. burgdorferi B31 labeled with lectin DBA directly conjugated with gold particles. Fig. 3. Negatively stained Borrelia afzelii and their outer membrane vesicles (arrow) double labeled with both WGA (10 nm gold particles) and ConA (20 nm gold particles). Fig. 4. Spirochetes B. afzelii with released flagella (arrow) labeled as described in Fig. 3 and negatively stained. Fig. 5. Longitudinal cryosection of $B$. burgdorferi B31 with gold-marked WGA-binding sites. Scale bars: Fig. $1,3=200 \mathrm{~nm}$; Fig. $2=50 \mathrm{~nm}$; Figs. 4, $5=100 \mathrm{~nm}$.

glycolipids are highly antigenic and might be considered as promising candidates for diagnosis or vaccination (Hossain et al. 2001, Ben-Menachem et al. 2003, Schröder et al. 2003). However, during the last two decades a significant change of perception has taken place regarding prokaryotic glycoproteins. Glycosylation of proteins is no longer considered a specific feature of eukaryotic organisms but has been demonstrated in many archea and bacteria. Besides the occurrence of glycosylated bacterial enzymes and antigens, surface layer glycoproteins represent the best-studied examples of glycosylated prokaryotic proteins (Schäffer et al. 2001).

Sambri et al. $(1992,1993)$ showed that even the outer surface proteins/lipoproteins OspA and OspB of several isolates of the LB spirochetes are major glycosylated proteins. These results are consistent with data published by Dorward and Garon (1990). However, since that time, reliable evidence on glycosylation of the major outer surface proteins has not been published. The LB spirochete glycoconjugates with different oligosaccharide structures were distinguished with labeled lectin probes in lectin affinity blotting or electron microscopy (Hulínská et al. 1992, Stoitsova et al. 2003). Figs. 2-5 show borrelia spirochetes labeled with lectin probes. A high-mannose glycan structure was detected in an 83$\mathrm{kDa}$ glycoprotein (major extracellular protein, predominantly present in the membrane vesicles) (Fig. 6); at least four carbohydrates (glucose or mannose, galactose, $\mathrm{N}$-acetylgalactosamine, and $\mathrm{N}$-acetylglucosamine) were present in other borrelia glycoconjugates. N-acetylneuraminic (sialic) acid was detected on the borrelia surface as well (Hulínská et al. 1991, 1992). Currently performed research on the occurrence of sialic acid in borrelia spirochetes has not proved spirochetal origin of the sialic acid. It seems that most of the detected sialic acid molecules come along with serum glycoproteins in the cultivation media (Vancová et al. 2005). The occurrence of polysialic acid in the bacterial capsules is always a very important indication of bacterial pathogenicity. The different polysialic acids expressed by Neisseria meningitidis are major virulence factors and are used as epidemiological markers and vaccine targets (Swartley et al. 1997). Also, polysialic acid and poly- 


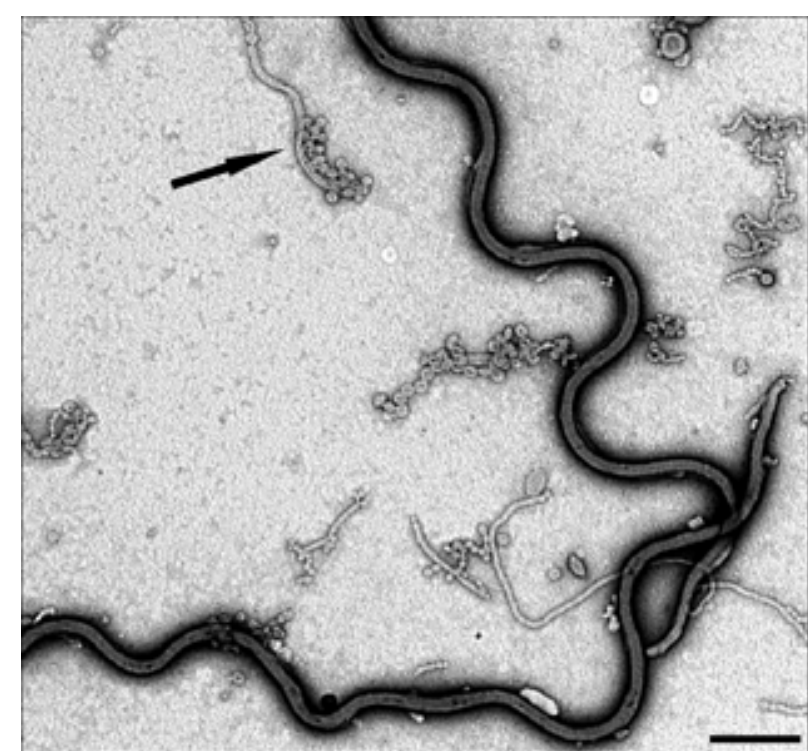

Fig. 6. Negative staining of cultured Borrelia burgdorferi spirochetes and their membrane vesicles (arrow). Scale bar $=2$ $\mu \mathrm{m}$.

sialyltransferase were found in Escherichia coli $\mathrm{K} 92$ (McGowen et al. 2001).

At least one additional borrelia glycosylated protein, FlaA (P37), is known. FlaA is an outer sheath protein of the periplasmic flagella and is glycosylated in contrast to the major protein FlaB of the periplasmic flagella (Ge et al. 1998, Gilmore et al. 1999). The protein FlaA elicits an early IgM antibody response in LB patients.

\subsection{Lectins/agglutinins of $L B$ spirochetes}

The first findings of borrelia in the linkage to the haemagglutination activity of the lysate of $B$. burgdorferi and $B$. recurrentis spirochetes were reported by Grubhoffer et al. (1992, 1993). Unlike results of Leong et al. (1995), the binding specificity of the borrelia (B31) lectin/agglutinin toward D-galactosamine, Dmannosamine and fetuin were recorded. The full gene that codes borrelia lectin was isolated from the genome of the spirochete using degenerated primers designed from sequences of already known lectin genes (about 100 genes were compared). The study of the 825 -bp lectin gene from B. burgdorferi B31 showed the possibility of the existence of two forms of predicted protein LEC1/2. Further analysis of the obtained sequences and their comparison with the molecular databases enabled the authors to determine the proper ORF of 274 amino acids, which should represent the functional region of the lectin molecule from B. burgdorferi B31. It corresponds to the BB0725 region of the borrelia genome (Fraser et al. 1997). The predicted amino acid sequence showed that this fragment contains the conservative domain typical of the lectins from seeds of Phaseolus vulgaris PHA-E a PHA-L. Of importance also is the fact that according to GenBank data the fragment of 274 amino acids revealed a high homology ( $94 \%$ identity) with the conserved hypothetical protein that is mentioned the first time by Fraser et al. (1997). The borrelia lectin gene was designated as lecB31 for further use (Rudenko et al. 1999), and its sequence was registered in the GenBank by number AF028001 NCBI (gil3138928). The entire sequence now is completed and codes for both forms of LEC molecules (LEC1/2, short/long form). This enables researchers to clone it and obtain the recombinant LEC protein (Rudenko et al. 2001).

Unlike the LEC31 borrelia lectin, the other haemagglutinin described by Leong et al. (1995) and Parveen and Leong (2000) is a protein of molecular size of 26 $\mathrm{kDa}$ with the binding affinity for glycosaminoglycans (GAGs). The latter authors have called it the Borrelia GAG-binding protein (Bgp). GAG as heparin or heparan sulfate, dermatan sulfate and chondroitin sulfate were found the most efficient inhibitors of red blood cell agglutination by Bgp (Parveen and Leong 2000). The gene encoding Bgp is located on spirochetal chromosome at BB0375 site (Parveen and Leong 2000, Frazer et al. 1997). The GAG-binding preference of a borrelia spirochete strain reflects in its cell-type-specific binding (Parveen et al. 1999). Borrelia strains that recognized predominantly heparan sulfate bound efficiently to endothelial cells, whereas strains with binding affinity to dermatan sulfate bound very well only epithelial cells. Host cell attachment may be critical for tissue colonisation. Besides Bgp there are two other GAGbinding proteins, which are called decorin-binding proteins $\mathrm{A}$ and $\mathrm{B}(\mathrm{DbpA}, \mathrm{DbpB})$ after human proteoglycan decorin (Guo et al., 1995, 1998). Parveen et al. (2003) have shown that three LB spirochetes surface proteins, Bgp, DbpA and DbpB bind to GAGs or GAG-containing molecules, and they might be considered as molecular factors of borrelia spirochetes invasion in the mammalian host organism. Till now there are no data about GAGs in ticks as well as a role of Bgp and $\mathrm{DbpA} / \mathrm{B}$ inside of tick vectors of LB.

\section{TRANSMISSION OF LB SPIROCHETES AND PARTICIPATION OF LECTINS IN THE PATHOGEN-VECTOR INTERACTION}

Ticks as haematophagous parasites represent an important group of the vectors of viral, bacterial and protozoan causative agents of diseases. With respect to public health, the sheep tick Ixodes ricinus is the principal vector of tick borne encephalitis (TBE) virus and Borrelia burgdorferi s.l. spirochetes in western and central Europe, while Ixodes persulcatus is most important in Eurasia. Ixodes scapularis and Ixodes pacificus are the main vectors of $B$. burgdorferi in eastern and western North America, respectively.

\subsection{Ticks as the vectors of $L B$ spirochetes}

Ixodes ricinus is a competent vector of $B$. burgdorferi s.l. spirochetes. Unlike TBE virus, borrelia spirochetes 
are extracellular parasites with significantly different pathophysiology of systemic infection of the vector. Spirochetes, conspicuously aggregated (by a lectin?) are localised between epithelial cells of the gut and attached to basal membrane in the early phase of infection (Burgdorfer et al. 1989). Other authors (Benach et al. 1987, Ribeiro et al. 1987) observed penetration of spirochetes from the gut to the haemocoel only in the early phase (3-5 days after attachment). Later, in the phase of systemic infection, spirochetes may be found there only sporadically. Therefore, such pathophysiology of borrelia infection may be involved in the regulation of systemic infection of the tick defence mechanisms in haemolymph. The lectin that was found in the haemolymph of I. ricinus (Grubhoffer et al. 1991, Kuhn et al. 1996) may be a molecular factor of the defensive mechanism that serves to restrict systemic infection of the vector by borrelia spirochetes. This lectin has the binding specificity to sialic acid and, therefore, may interact with lipooligosaccharides of the spirochete's outer membrane due to a steric similarity of sialic acid with 2-keto-3-deoxyoctonate acid, or with sialic acid itself. The presence of sialic acid in the wall of $B$. burgdorferi was proposed in 1991 (Hulínská et al. 1991). LB spirochetes also have other glycosylated components or glycoconjugates on their surface (like "slime layer" component or the "major extracellular protein" [MEP] of $83 \mathrm{kDa}$ ). The latter one, however, has never been proved and according to Shoberg and Thomas (1995), MEP is an artificial structural unit at borrelia surface that might also provide suitable target ligands from other tissue lectins of the ticks. Other factors with lectin or lectin-like binding activity may also interact with structural components of B. burgdorferi in the salivary glands or in saliva itself. During the systemic infection, B. burgdorferi spirochetes may be found in both type I and granular acini of salivary glands, where they pass through into the lumen of the acinus, and then can be transported into the saliva (Zung et al. 1989, Friedhoff 1990). Saliva containing glycoproteins of unknown function, esterase and some pharmacologically efficient substances, make the transmission of B. burgdorferi significantly easier by decreasing the functional activity of host neutrophils (Ribeiro 1987, Walker and Fletcher 1990).

\subsection{Tick-borrelia immune interactions}

In recent years, the immune response of $I$. ricinus and the major American vector of B. burgdorferi s.l., I. scapularis, have been investigated with respect to the innate immune response of the ticks to several bacteria (Johns et al. 1998, 2000, 2001). These studies have focused primarily on bacterial survival in the tick, observations of phagocytosis and finding evidence of antibacterial peptides in the haemolymph. During this time, progress has been made in understanding the molecular basis of vector-parasite compatibility and the cellular interactions between mosquitoes and malaria parasites
(Barrilas-Mury et al. 2000, Christophides et al. 2004). In contrast, very little has been published on mechanisms of molecular interactions between tick vectors and $B$. burgdorferi spirochetes.

The midgut is the first site of interaction between ticks and B. burgdorferi. Unlike other tick-borne borrelia spirochetes that leave the midgut of their vector shortly after ingestion and cause either a haemocoellimited or a systemic infection, B. burgdorferi spirochetes remain in the tick midgut, where they aggregate within the microvillar brush-border and in the intracellular space between epithelial cells. From the midgut, $B$. burgdorferi may penetrate the gut wall during and after blood feeding and may initiate a systemic infection (Burgdorfer et al. 1989). Regardless of such generalised infections, the midgut remains infected throughout the life span of the tick. Since the tick gut is the principal site where B. burgdorferi persist in the vector, and the spirochetes almost exclusively reside within this tissue during the long intervals between the tick blood meals, it is likely that B. burgdorferi has evolved mechanisms to specifically interact with arthropod receptors within the gut. Some tick proteins, binding to OspA, that play an important role in spirochete-vector interactions have been described (Pal et al. 2004b).

The physiological mechanisms of vector competence in various tick species remain to be explained and require further studies. Mátlová et al. (1996) showed that unlike Ixodes ricinus, another hard tick Dermacentor reticulatus reveals a gradual decline and the loss of LB spirochetes shortly after infection. This indicates a lack of this ixodid species to serve as a competent vector of B. burgdorferi. Regarding vector competence of $I$. ricinus and $D$. reticulatus, the effect of both salivary gland and midgut extracts on the growth of LB spirochetes in vitro was tested (Rudolf and Hubálek 2003). While extract derived from I. ricinus (a competent vector) stimulated growth significantly, extracts from $D$. reticulatus (a non-competent vector) did not affect the growth of borreliae markedly, or even inhibited borrelia growth in vitro.

To infect a subsequent host, the bacteria must escape the tick gut and migrate to the salivary glands. During this migratory stage, the spirochetes are exposed to the tick's cellular defence or anti-bacterial peptides in the haemocoel. Ticks have an open circulatory system that functions in fluid transport of nutrients and in the defence response against pathogens. Plasmatocytes and granulocytes are active components of such cellular defence response. Both are involved in recognition and phagocytosis of foreign bodies, and the encapsulation response of ticks occurs in a similar manner as it does in insects. The process includes degranulation of granulocytes followed by deposition of the matrix on the surface of the foreign body and the formation of a multicellular layer of granulocytes and plasmatocytes (Eggenberger et al. 1990). In the American dog tick Dermacen- 
tor variabilis, infection with $B$. burgdorferi results in an increase of plasma borreliacidal factors and a six-fold rapid increase in phagocytic cells to clear the infection and limit tissue invasion (Johns et al. 1998, 2000, 2001). Phagocytosis of B. burgdorferi by haemocytes has been reported in I. scapularis (Coleman et al. 1997). In this study, haemocytes with bound or incorporated spirochetes increased gradually, from only $2 \%$ of the haemocyte population on feeding day 3 to $13 \%$ by feeding day 5 . Haemocyte abundance was distinctly higher in the $B$. burgdorferi-challenged $I$. scapularis ticks for at least 1 $\mathrm{h}$ after spirochete inoculation, suggesting that an increase in the number of haemocytes may contribute to the eventual clearance of spirochetes.

Inducible humoral defensive proteins have not been as well characterized in ticks as they have in some insects. Nevertheless, two isoforms of a member of the arthropod defensin family have been cloned from Ornithodoros moubata (Nakajima et al. 2001). Importantly, Ornithodoros defensin mRNA is up-regulated by blood feeding and bacterial injection. Also, an anti-bacterial humoral response against the protozoan parasite Theileria parva was recently investigated in its tick vector, Rhipicephalus appendiculatus (Watt et al. 2001). The exoskeletons of adult ticks were initially pierced with one of three type needles: (1) bacteria-coated, (2) salinecoated, or (3) sterile dry glass. Haemolymph was extracted from the ticks at $6,24,48$, and $72 \mathrm{~h}$ postinjection and applied to bacterial plates to measure the growth inhibition effects. The inhibition zones were larger with all the injected groups compared to uninjected controls. The largest inhibition zones were seen $24 \mathrm{~h}$ after injection with bacteria-coated needles.

Ixodes scapularis, a major vector of $B$. burgdorferi spirochetes, has a significantly less robust response against $B$. burgdorferi than the incompetent vector American dog tick, Dermacentor variabilis (Johns et al. 2001). Following intrathoracic inoculation, some Borrelia spirochetes were found associated with I. scapularis haemocytes, while the majority of intact bacteria remained free in the haemolymph. In contrast, in D. variabilis only remnants of the bacteria were evident in the haemolymph, indicating lysis; intact spirochetes were rare. Spirochetes were observed bound to or within organs of both tick species, although many more spirochetes were found associated with organs of I. scapularis. The few spirochetes observed in D. variabilis appeared to be dead because $D$. variabilis tissues rarely contained cultivable bacteria, unlike those isolated from I. scapularis tissues. When spirochetes were incubated with haemolymph plasma of I. scapularis in vitro, bacterial survival and motility were not reduced. In contrast, incubation of spirochetes with $D$. variabilis haemolymph plasma resulted in $>50 \%$ of the spirochetes becoming nonmotile by $45 \mathrm{~min}$. The differences in the responses of these two different tick species indicate that I. scapularis is relatively immunotolerant when challenged with $B$. burgdorferi compared to $D$. variabilis. I. scapularis may depend on a slow phagocytic response to clear borreliae from the haemolymph. In contrast, D. variabilis is highly immunocompetent, using plasma borreliacidal factors and a rapid increase in phagocytic cells to clear the infection and limit tissue invasion.

Other experimental data suggest a high level of variability in the response of $I$. scapularis and I. ricinus against borrelia infection. Also, responses to different strains of bacteria have been shown to differ markedly (Dolan et al. 1998). In these experiments, the vector competence of $I$. ricinus and $I$. scapularis was determined and compared with two strains of $B$. burgdorferi s.s. (B-31 and B-31.D1 clone), B. afzelii (strain Pgau. C3), and B. garinii (strains VS286 and VSBP). Tick larvae were assayed for infection by culture in media every 7 days for 4 weeks. Infection frequencies in $I$. scapularis exposed to the five strains were as follows: B-31 (90\%), B-31.D1 (83\%), Pgau.C3 (87\%), VS286 $(10 \%)$, and VSBP $(5 \%)$. The comparable infection frequencies for $I$. ricinus were B-31 (3\%), B-31.D1 (3\%), Pgau.C3 (90\%), VS286 (5\%), and VSBP (3\%). Nymphal I. scapularis successfully transmitted B-31, B31.D1, Pgau.C3, and VS286 to outbred mice. Nymphs of $I$. ricinus transmitted Pgau.C3 and VS286. Both species failed to transmit strain VSBP. Although I. ricinus ticks do not have a robust immune response, it is likely that they are capable of innate reaction. It is now appreciated that $B$. garinii includes strains that cannot infect rodents (the majority) and a serotype 4 that can infect rodents. This fact might have influenced the results obtained by Dolan et al. (1998).

\subsection{Lectins as carbohydrate-binding proteins in tick- spirochete interaction}

Currently, even partially characterized tick lectins show significantly various affinities to sialic acid and to $\mathrm{N}$-acetyl-D-glucosamine and differ in their binding specificity to other sugars. Their interaction with glycosylated structures of transmitted pathogens is suspected, but has not yet been proved (for review, Grubhoffer et al. 2004). However, some data in support of this expectation have appeared recently. The first lectin studies were done on haemolymph of the soft ticks Ornithodoros tartakovskyi, O. papillipes and Argas polonicus (Grubhoffer et al. 1991). Afterwards, Kamwendo et al. (1993) reported haemagglutinating activities in haemolymph, gut homogenates, and salivary glands in the hard tick Rhipicephalus appendiculatus, the field vector of East Coast fever (a tick-borne disease of cattle caused by the protozoan parasite Theileria parva). Bovine red blood cells were found as the most sensitive detection system for all of these activities possessing no significant differences between those in extracts from unfed and fed ticks. The highest increase was recorded in the gut extract. Kamwendo et al. (1995) dealt with a specific functional role of the tick salivary gland 

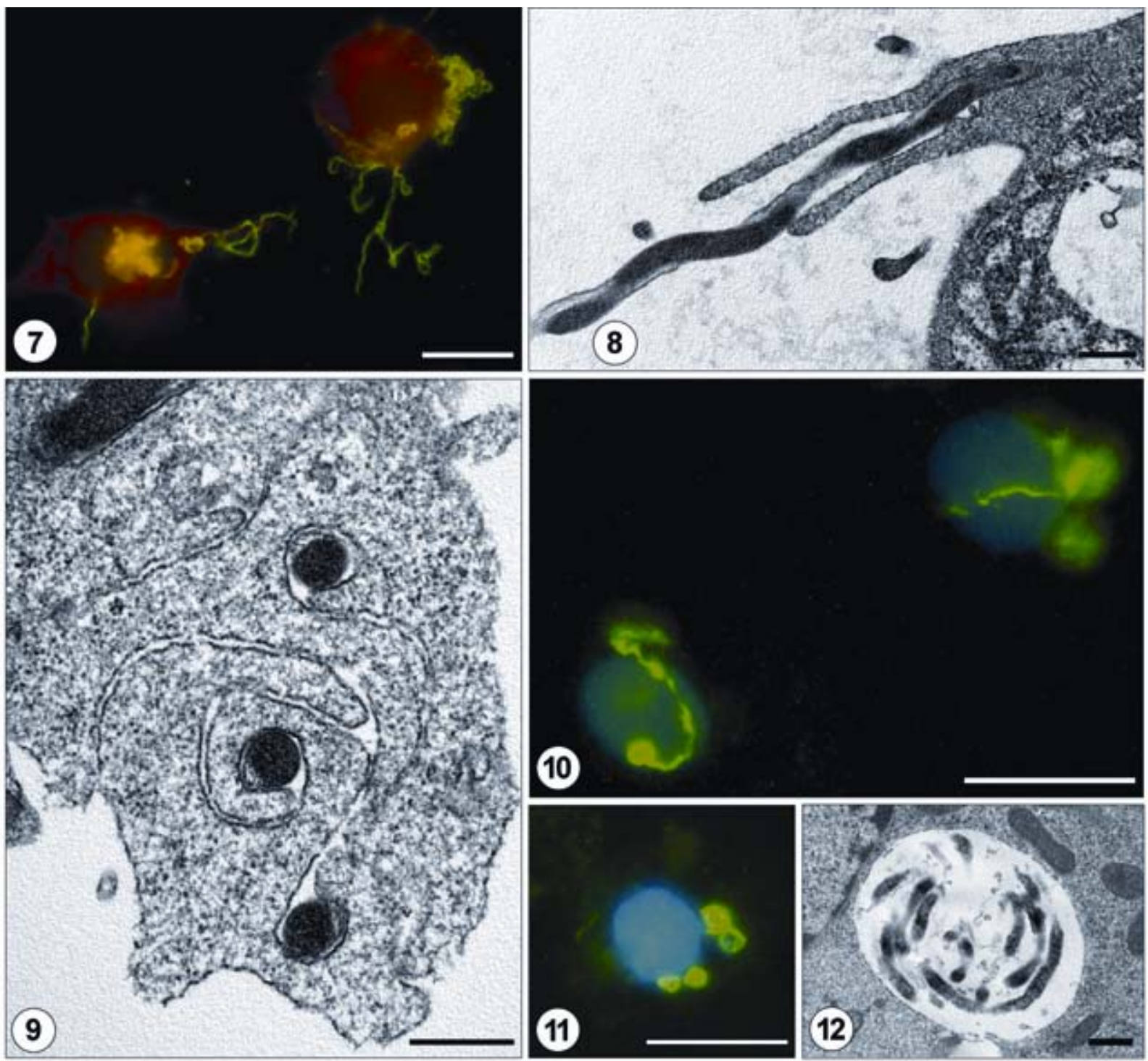

Figs. 7-12. Isolated haemocytes of Ixodes ricinus and their interactions with Borrelia burgdorferi B31 in vitro. Fig. 7. The adhesion of the ends of B. burgdorferi cells to the surface of haemocytes. Fig. 8. Phagocytosis of B. burgdorferi via symmetrical phagocytic cup (conventional phagocytosis). Fig. 9. A haemocyte engulfing B. burgdorferi spirochetes via overlapping pseudopods (coiling phagocytosis). Fig. 10. Two haemocytes with partially phagocytosed borrelia spirochetes. Fig. 11. Borrelia spirochetes coiled in phagosomes of a haemocyte. Fig. 12. An ultrathin section of coiled B. burgdorferi residing within phagosome. Figs. 7, 10, $11-B$. burgdorferi labeled with anti-flagellin specific antibodies followed by FITC-conjugated secondary antibodies; Figs. 10, 11 - nuclei stained with DAPI; Fig. 7 - cytoplasm stained with Evans blue; Figs. 7, 10, 11 - fluorescence microscopy; Figs. 8, 9, 12 -transmission electron microscopy. Scale bars: Figs. 7, 10, $11=10 \mu \mathrm{m}$; Figs. 8, 9, $12=500 \mathrm{~nm}$. (From Slavíčková 2004.)

haemagglutinin of $R$. appendiculatus, searching for a mechanism of $T$. parva transmission. A significant increase in infection rates of $T$. parva occurred in salivary gland acini of $R$. appendiculatus that were fed on ears of rabbits infused with mellibiose and raffinose. In contrast, mannose and turanose (non-inhibitory sugars) did not cause an elevation of $T$. parva acinar infection rates.

Haemagglutination activity has been found and partially characterized in a midgut homogenate of $I$. ricinus (Uhlír et al. 1996). Native mouse erythrocytes were the most sensitive detection cell system in a wide $\mathrm{pH}$ range of 6.5-8.0. Binding specificity analysis has shown that the simple sugars N-acetyl-D-galactosamine, N-acetylD-glucosamine, rhamnose, dulcit and glycoconjugates fetuin, hyaluronic acid, laminarin (beta 1,3-glucan) and bacterial lipopolysaccharides are the molecules with the highest inhibitory effect in haemagglutination assays. Midgut extracts from unfed ticks lack haemagglutination activity. Mouse polyclonal antibodies raised against midgut haemagglutination activity have discriminated on western blot gels four protein molecules of 37,60 , 65 , and $73 \mathrm{kDa}$. These are putative structural compo- 
nents of the lectin(s) or the whole haemagglutination complex. A protein with a molecular size of $65 \mathrm{kDa}$ was found to be the main agglutinin with binding affinity to highly sialylated bovine submaxillary mucin, whereas the other purified protein of about $37 \mathrm{kDa}$ had a strong binding specificity for laminarin (beta-1,3 glucan) (Durnová 1998). Compounds of 37 and 60 kDa are glycoproteins modified by both high mannose and complex types of N-glycans; a $70 \mathrm{kDa}$ subunit is likely modified only by complex glycans (Uhlír et al. 1994). Using the specific mouse polyclonal antibodies, the midgut haemagglutinin has been immunohistologically localised only in the midgut cells, and not in the gut content or other tick tissues including haemolymph.

Agglutinins found in haemolymph/haemocytes and in salivary gland extract of adult $I$. ricinus are apparently lectins that have different binding features than those in the midgut (Grubhoffer et al. 1991, Grubhoffer and Durnová 1996, Kuhn et al. 1996, Grubhoffer and Kovár 1998). Haemolymph/haemocyte haemagglutinin has been characterized as an $85-\mathrm{kDa} \mathrm{Ca} 2^{+}$-dependent, sialic acid-binding lectin with additional affinity for $\mathrm{N}$-acetylD-glucosamine and D-galactose (Grubhoffer et al. 1991). Ixodes ricinus haemolymph lectin was immunolocalised in tick tissues and its distribution supports the hypothesis that the lectin is produced and/or stored in haemocytes and contributes to the immune system of the tick by recognition of foreign substances (Kuhn et al. 1996). Lectin molecules were detected in the granules of both types of granular haemocytes, the membrane of haemocytes, the basal laminae surrounding the haemocoel, cells attached to the midgut, invaginations of Géne's organ, and granular inclusions of nephrocytes (Kuhn et al. 1996). Like Dorin M, the sialic acidspecific plasma lectin of the soft tick Ornithodoros moubata (Grubhoffer and Kovář 1998, Kovář et al. 2000, Rego et al. 2005 a, b) and some other sialic acidspecific lectins of chelicerates, the haemolymph lectin (Ixoderin A) of ixodid ticks may also recognize a wide range of gram-negative bacteria due to its binding specificities for N-acetyl-D-glucosamine, D-galactose and 2keto-3-deoxyoctonate acid (Vasta and Marchalonis 1983, Grubhoffer et al. 1991, Kuhn et al. 1996). Dorin $\mathrm{M}$ is the first lectin purified from ticks which was cloned as well. It remains to be proved whether $I$. ricinus plasma lectin has a structural similarity to Dorin $\mathrm{M}$ or not. Rittig et al. (1996) report that the haemocytes of $I$. ricinus phagocytose the borrelia spirochetes by the "coiling-way" (Figs. 7-12). Coiling phagocytosis is likely a lectin-mediated process described in many other cases (Kuhn et al. 1994, Slavíčková 2004).

Agglutinin in the tick salivary gland extracts has been determined to be a lectin with the structural subunit of $70 \mathrm{kDa}$ and the binding specificity for sialic acid and some other saccharides (D-mannosamine, N-acetylD-galactosamine, trehalose), and for sialylated glycoproteins as well (Grubhoffer and Durnová 1996).

Based on the binding characteristics, the tick midgut agglutinin can function as a LPS-binding protein analogous to carbohydrate binding activities in the gut tissue of other blood sucking arthropods. It appears that the midgut agglutinin is a potential LPS-binding protein that might play a key role in cooperation with the digestive enzymes once gram-negative $B$. burgdorferi spirochetes have penetrated the gut epithelium/wall into the haemocoel. Sialic acid-binding lectins from haemolymph and salivary glands might be able to bind borrelia cells by interactions with sialic acid or with steric ana$\operatorname{logs}$ of sialic acid, structural parts of the borrelia lipopolysaccharide or lipooligosaccharide.

\section{CONCLUSION}

LB is an infectious disease of humans and some other mammals and is a complex public health problem both epidemiologically and ecologically. By definition, it represents exoanthropic zoonoses outside human habitats (Hubálek 2003). Each functional unit of the 'tickborrelia-host' system may have been in an interaction with external or internal environment, and those interactions are performed at the level of organisms as well as molecules. Although it has yet to be proven, it is likely that specific protein(lectin)-carbohydrate interactions might be involved in the process of transmission of LB spirochetes by ticks. If so, then those interactions may function as reciprocal ones, where tissue-specific tick lectins may enter counterpart interactions equally as lectins of LB spirochetes. Carbohydrate/glycan moieties of the membrane-bound or soluble proteins in tick tissues may serve as receptors of those lectin molecules (Grubhoffer et al. 1997). Based on published results, a binding affinity to sialic acid and their derivatives or steric analogs has been revealed as a common feature of tissue-specific tick lectins. Sialic acid as well as its analogs appear to be receptor candidates for those interactions. Currently, lectins are considered as one of 'pattern recognition proteins', which are considerably employed in mechanisms of recognition of foreign material and of innate immunity.

Acknowledgements. This study was funded by the Grant Agency of the Czech Republic (524/03/1326 and 206/03/ 1323), the Ministry of Education, Youth and Sports (MSM 6007665801), NATO Science Senior Fellowship 8 (2003), Science and Technology collaboration between ASCR and NRC Canada (Z60220518/58-8500), and by grant R37 AI24899 from the U.S. National Institutes of Health. 


\section{REFERENCES}

ASSOUS M., POSTIC D., PAUL G., NEVOT P., BARANTON G. 1993: Western blot analysis of sera from Lyme borreliosis patients according to the genomic species of the Borrelia strains used as antigen. J. Clin. Microbiol. Infect. Dis. 12: 261-268.

BABB K., El-HAGE N., MILLER J.C., CARROL J.A., STEVENSON B. 2001: Distinct regulatory pathway control expression of Borrelia burgdorferi infection-associated OspC and Erp surface proteins. Infect. Immun. 69: 41464153.

BARANTON G., ASSOUS M., POSTIC D. 1992: Three bacterial species associated with Lyme borreliosis. Clinical and diagnostic implications Bull. Acad. Natl. Med. 176: $1075-1085$.

BARANTON G., POSTIC D., SAINT GIRONS I., BOERLING P., PIFFARETTI J.C., ASSOUS M., BUNIKIS J., LUKE C.J., BUNIKIENE E., BERGSTRÖM, BARBOUR A.G. 1998: A surface-exposed region of a novel outer membrane protein (P66) of Borrelia spp. is variable in size and sequence. J. Bacteriol. 180: $1618-1623$.

BARANTON G., SEINOST G., THEODORE G., POSTIC D., DYKHUIYEN D. 2001: Distinct levels of genetic diversity of Borrelia burgdorferi are associated with different aspects of pathogenicity. Res. Microbiol. 152: 149-156.

BARBOUR A.G. 1988: Plasmid analysis of Borrelia burgdorferi, the Lyme disease agent. J. Clin. Microbiol. 26: 475478.

BARBOUR A.G., HAYES S.F. 1986: Biology of Borrelia species. Microbiol. Rev. 50: 381-400.

BARILLAS-MURY C., WIZEL B., HAN Y.S. 2000: Mosquito immune responses and malaria transmission: lessons from insect model systems and implications for vertebrate innate immunity and vaccine development. Insect Biochem. Mol. Biol. 30: 429-442.

BENACH J.L., COLEMAN J.L., SKINNER R.A., BOSLER E.M. 1987: Adult Ixodes dammini on rabbits: hypothesis for the development and transmission of Borrelia burgdorferi. J. Infect. Dis. 155: 1300-1306.

BEN-MENACHEM G., KUBLER-KIELB J., COXON B., YERGEY A., SCHNEERSON R. 2003: A newly discovered cholesteryl galactoside from Borrelia burgdorferi. Proc. Natl. Acad. Sci. U.S.A. 100: 7913-7918.

BERGSTRÖM S., NOPPA L., GYLFE A., ÖSTBERG Y. 2002: Molecular and cellular biology of Borrelia burgdorferi sensu lato. In: O. Kahl, J.S. Gray, R.S. Lane and G. Stanek (Eds.), Lyme Borreliosis: Biology, Epidemiology and Control. CABI Publishing, Oxford, United Kingdom, pp. 47-90.

BRORSON O., BRORSON S.H. 1998: In vitro conversion of Borrelia burgdorferi to cystic forms in spinal fluid, and transformation to mobile spirochetes by incubation in BSK-H medium. Infection 26: 144-150.

BURGDORFER W. 2001: Arthropod-borne spirochetosis: a historical perspective. Eur. J. Clin. Microbiol. Dis. 20: 15.

BURGDORFER W., BARBOUR A.G., HAYES S.F., BENACH J.L., GRUNDWALDT E., DAVIS J.P. 1982: Lyme disease: a tick-borne spirochetosis? Science 216: 1317 1319.

BURGDORFER W., HAYES S.F., CORWIN D. 1989: Pathophysiology of the Lyme disease spirochete Borrelia burgdorferi, in ixodid ticks. Rev. Infect. Dis. 6: 127-150.

CANICA M.M., NATO F., DU MERLE L., MAZIE J.C., BARANTON G., POSTIC D. 1993: Monoclonal antibodies for identification of Borrelia afzelii sp. nov. associated with late cutaneous manifestations of Lyme borreliosis. Scand. J. Infect. Dis. 25: 441-448.

CHRISTOPHIDES G.K., VLACHOU D., KAFATOS F.C. 2004: Comparative and functional genomics of the innate immune system in the malaria vector Anopheles gambiae. Immunol. Rev. 198: 127-148.

COLEMAN J.L., GEBBIA J.A., PIESMAN J., DEGEN J., BUGGE T.H., BENACH J.L. 1997: Plasminogen is required for efficient dissemination of B. burgdorferi in ticks and for enhancement of spirochetemia in mice. Cell 89: 1111-1119.

COLEMAN J.L., ROEMER E.J., BENACH J.L. 1999: Plasmin-coated Borrelia burgdorferi degrades soluble and insoluble components of the mammalian extracellular matrix. Infect. Immun. 67: 3929-3936.

COLLARES-PEREIRA M., COUCEIRO S., FRANCA I., KURTENBACH K., SCHÄFER S.M., VITORINO L., GONCALVES L., BAPTISTA S., VIEIRA M.L., CUNHA C. 2004: First isolation of Borrelia lusitaniae from a human patient. J. Clin. Microbiol. 42: 1316-1318.

DE SILVA A.M., FIKRIG E. 1997: Borrelia burgdorferi genes selectively expressed in ticks and mammals. Parasitol. Today 13: 267-270.

DEFOE G., COBURN J. 2001: Delineation of Borrelia burgdorferi p66 sequences required for integrin alpha(IIb)beta(3) recognition. Infect. Immun. 69: 34553459.

DEMAERSCHALCK I., MESSAOUD A.B., KESEL M. De, HOYOIS B., LOBET Y., HOET P., BIGAIGNON G., BOLLEN A., GODFROID E. 1995: Simultaneous presence of different Borrelia burgdorferi sensu lato genospecies in biological fluids of Lyme disease patients. J. Clin. Microbiol. 33: 602-608.

DENNIS D.T., HAYES E.B. 2002: Epidemiology of Lyme borreliosis. In: O. Kahl, J.S. Gray, R.S. Lane and G. Stanek (Eds.), Lyme Borreliosis: Biology, Epidemiology and Control. CABI Publishing, Oxford, United Kingdom, pp. 251-280.

DERDÁKOVÁ M., BEATI L., PET'KO B., STANKO M., FISH D. 2003: Genetic variability within Borrelia burgdorferi sensu lato genospecies established by PCRsingle-strand conformation polymorphism analysis of the rrfA-rrlB intergenic spacer in Ixodes ricinus ticks from the Czech Republic. Appl. Environ. Microbiol. 69: 509-516.

DOLAN M.C., PIESMAN J., MBOW M.L., MAUPIN G.O., PETER O., BROSSARD M., GOLDE W.T. 1998: Vector competence of Ixodes scapularis and Ixodes ricinus (Acari: Ixodidae) for three genospecies of Borrelia burgdorferi. J. Med. Entomol. 35: 465-470. 
DORWARD D.W., GARON C.F. 1990: Glycosylation of proteins associated with extra cellular membrane vesicles in Borrelia burgdorferi. IV. Int. Conf. Lyme Borreliosis, Stockholm, June 18-21, 1990, Abstract M/TU-P-12.

DURNOVÁ E. 1998: [Midgut agglutinins (lectins) of common sheep tick, Ixodes ricinus L. (Ixodida, Ixodidae): isolation and partial characterization.] MSc thesis, University of South Bohemia, České Budějovice, 44 pp. (In Czech, unpubl.)

EGGENBERGER L.R., LAMOREAUX W.J., COONS L.B. 1990: Hemocytic encapsulation of implants in the tick Dermacentor variabilis. Exp. Appl. Acarol. 9: 279-287.

ELIAS A.F., STEWART P.E., GRIMM D., CAIMANO M.J., EGGERS C.H., TILLY K., BONO J.L., AKINS D.R., RADOLF J.D., SCHWAN T.G., ROSA P. 2002: Clonal polymorphism of Borrelia burgdorferi strain B31 MI: implications for mutagenesis in an infectious strain background. Infect. Immun. 70: 2139-2150.

FENG S., HODZIC E., STEVENSON B., BARTHOLD S. 1998: Humoral immunity to Borrelia burgdorferi N40 decorin binding proteins during infection of laboratory mice. Infect. Immun. 66: 2827-2835.

FRASER C.M., CASJENS S., HUANG W., SUTTON G., CLAYTON R., LATHIGRA R., WHITE O., KETCHUM K.A., DODSON R., HICKEY E.K., GWINN M., DOUGHERTY B., TOMB J.F., FLEISCHMANN R.D., RICHARDSON D., PETERSON J., KERLAVAGE A.R., QUACKENBUSH J., SALZBERG S., HANSON M., et al. 1997: Genome of Lyme disease pathogen. Nature 390: $580-586$.

FRIEDHOFF K.T. 1990: Interaction between parasite and tick vector. Int. J. Parasitol. 20: 525-535.

FRIEDLANDER A.M., WELKOS S.L., WORSHAM P.L., ANDREWS G.P., HEATH D.G., ANDERSON G.W. Jr., PITT M.L., ESTEP J., DAVIS K. 1995: Relationship between virulence and immunity as revealed in recent studies of the F1 capsule of Yersinia pestis. Clin. Infect. Dis. 21: S178-S181.

FUCHS H., WALLICH R., SIMON M.M., KRAMER M.D. 1994: The outer surface protein A of the spirochete Borrelia burgdorferi is a plasmin(ogen) receptor. Proc. Natl. Acad. Sci. U.S.A. 91: 12594-12598.

FUKUNAGA M., HAMASE A., OKADA K., NAKAO M. 1996: Borrelia tanukii sp. nov. and Borrelia turdae sp. nov. found from ixodid ticks in Japan: rapid species identification by $16 \mathrm{~S}$ rRNA gene-targeted PCR analysis. Microbiol. Immunol. 40: 877-881.

FUKUNAGA M., TAKAHASHI Y., TSURUTA Y., MATSUSHITA O., RALPH D., McCLELLAND M., NAKAO M. 1995: Genetic and phenotypic analysis of Borrelia miyamotoi sp. nov., isolated from the ixodid tick Ixodes persulcatus, the vector for Lyme disease in Japan. Int. J. Syst. Bacteriol. 45: 804-810.

GARCIA-MONCO J.C.G., FERNANDEZ VILLAR B., ROGERS R.C., SZCZEPANSKI A., WHEELER C.M., BENACH J.L. 1992: Borrelia burgdorferi and other related spirochetes bind to galactocerebroside. Neurology 42: $1341-1348$.

GARON C.F., DORWARD D.W., CORWIN M.D. 1989: Structural features of Borrelia burgdorferi - the Lyme disease spirochete: silver staining for nucleic acid. Scann. Microsc. 3: 109-115.

GE Y., CORUM L., SLAUGHTER C.A., CHARON N.W. 1998: Structure and expression of the FlaA periplasmic flagellar protein of Borrelia burgdorferi. J. Bacteriol. 180: 2418-2425.

GERN L., HU C.M., KOCIANOVA E., VYROSTEKOVA V., REHACEK J. 1999: Genetic diversity of Borrelia burgdorferi sensu lato isolates obtained from Ixodes ricinus ticks collected in Slovakia. Eur. J. Epidemiol. 15: 665-669.

GILMORE R.D. Jr., MURPHREE R.L., JAMES A.M., SULLIVAN S.A., JOHNSON B.J.B. 1999: The Borrelia burgdorferi 37-kilodalton immunoblot band (P37) used in serodiagnosis of early Lyme disease is the fla $A$ gene product. J. Clin. Microbiol. 37: 548-552.

GRIMM D., TILLY K., BYRAM R., STEWART P.E., KRUM J.G., BUESCHEL D.M., SCHWAN T.G., POLICASTRO P.F., ELIAS A.F., ROSA P.A. 2004: Outersurface protein $\mathrm{C}$ of the Lyme disease spirochete: a protein induced in ticks for infection of mammals. Proc. Natl. Acad. Sci. U.S.A. 101: 3142-3147.

GRUBHOFFER L., DURNOVÁ E. 1996: A lectin in salivary glands of tick Ixodes ricinus: detection and partial characterization. XX Int. Congr. Entomol., Firenze, Italy, 1996, Proceedings, p. 746.

GRUBHOFFER L., HYPŠA V., VOLF P. 1997: Lectins (hemagglutinins) in the gut of the important disease vectors. Parasite 4: 203-216.

GRUBHOFFER L., KOVÁŘ V. 1998: Arthropod lectins: affinity approaches in the analysis and preparation of carbohydrate binding proteins. In: A. Wiesner et al. (Eds.), Techniques in Insect Immunology. FITC-5, SOS Publications, Fair Haven, NJ, pp. 47-57.

GRUBHOFFER L., RUDENKO N., KOVÁŘ V. 2004: Tick lectins: structural and functional properties. Parasitology 129 (Suppl.): S113-S126.

GRUBHOFFER L., VEREŠ J., DUSBÁBEK F. 1991: Lectins as the molecular factors of recognition and defence reactions of ticks. In: F. Dusbábek and V. Bukva (Eds.), Modern Acarology. Vol. 2. Academia Prague and SPB Academic, The Hague, pp. 381-388.

GRUBHOFFER L., UHLÍR J., VOLF P. 1992: Hemagglutination activity of Borrelia burgdorferi and B. recurrentis. 1st International Conference on Lyme Borreliosis, Prague, October 1992, Abstract 22.

GRUBHOFFER L., UHLÍŘ J., VOLF P. 1993: Functional and structural identification of a new lectin activity of Borrelia recurrentis spirochetes. Comp. Biochem. Physiol. 105B: 535-540.

GUIGNOT J., MOCK M., FOUET A. 1997: AtxA activates the transcription of genes harbored by both Bacillus anthracis virulence plasmids. FEMS Microbiol. Lett. 147: 203-207.

GUO B.P., BROWN E.L., DORWARD D.W., ROSENBERG L.C., HOOK M. 1998: Decorin-binding adhesins from Borrelia burgdorferi. Mol. Microbiol. 30: 711-723.

GUO B.P., NORRIS S.J., ROSENBERG L.C., HOOK M. 1995: Adherence of Borrelia burgdorferi to the proteoglycan decorin. Infect. Immun. 63: 3467-3472. 
HAGMAN K.E., LAHDANNE P., POPOVA P., PORCELLA T.G., AKINS S.F., RADOLF D.R., NORGARD M. 1998: Decorin-binding protein of Borrelia burgdorferi is encoded within a two-gene operon and is protective in the murine model of Lyme borreliosis. Infect. Immun. 66: 2674-2683.

HELlWAGE J., MERI T., HEIKKILÄ T., ALITALO A., PANELIUS J., LAHDENNE P., SEPPÄLÄ I.J.T., MERI S. 2001: The complement regulator factor $\mathrm{H}$ binds to the surface protein OspE of Borrelia burgdorferi. J. Biol. Chem. 276: 8427-8435.

HENGGE U.R., TANNAPFEL A., TYRING S.K., ERBEL R., ARENDT G., RUZICKA T. 2003: Lyme borreliosis. Lancet Infect. Dis. 3: 489-500.

HOSSAIN H., WELLENSIEK H.J., GEYER R., LOCHNIT G. 2001: Structural analysis of glycolipids from Borrelia burgdorferi. Biochimie 83: 683-692.

HUBÁLEK Z. 2003: Emerging human infectious diseases: anthroponoses, zoonoses, and sapronoses. Emerg. Infect. Dis. 9: 403-404.

HUBÁLEK Z., HALOUZKA J. 1998: Prevalence rates of Borrelia burgdorferi sensu lato in host-seeking Ixodes ricinus ticks in Europe. Parasitol. Res. 84: 167-172.

HULÍNSKÁ D., VOLF P., GRUBHOFFER L. 1991: Surface carbohydrates of Borrelia burgdorferi. In: F. Dusbábek and V. Bukva (Eds.), Modern Acarology. Vol. 2. Academia Prague and SPB Academic, The Hague, pp. 73-78.

HULÍNSKÁ D., VOLF P., GRUBHOFFER L. 1992: Study of Borrelia burgdorferi glycoproteins and surface carbohydrates by lectin conjugates. Zentralbl. Bakteriol. 276: 473480.

ISAACS R.D. 1994: Borrelia burgdorferi bind to epithelial cell proteoglycans. J. Clin. Invest. 93: 809-819.

JOHNS R., OHNISHI J., BROADWATER A., SONENSHINE D.E., DE SILVA A.M., HYNES W.L. 2001: Contrasts in tick innate immune responses to Borrelia burgdorferi challenge: immunotolerance in Ixodes scapularis versus immunocompetence in Dermacentor variabilis (Acari: Ixodidae). J. Med. Entomol. 38: 99-107.

JOHNS R., SONENSHINE D.E., HYNES W.L. 1998: Control of bacterial infections in the hard tick Dermacentor variabilis (Acari: Ixodidae): evidence for the existence of antimicrobial proteins in tick hemolymph. J. Med. Entomol. 37: $265-270$.

JOHNS R., SONENSHINE D.E., HYNES W.L. 2000: Response of the tick Dermacentor variabilis (Acari: Ixodidae) to hemocoelic inoculation of Borrelia burgdorferi (Spirochetales). J. Med. Entomol. 37: 265-270.

JOHNSON R.C., SCHMID G.P., HYDE F.M., STEIGERWALT A.G., BRENNER D.J. 1984: Borrelia burgdorferi sp. nov.: etiological agent of Lyme disease. Int. J. Syst. Bacteriol. 34: 496-497.

KAMRADT T. 2002: Lyme disease and current aspects of immunization. Arthritis Res. 4: 20-29.

KAMWENDO S.P., INGRAM G.A., MUSISI F.L., MOLYNEUX D.H. 1993: Haemagglutinin activity in tick (Rhipicephalus appendiculatus) haemolymph and extracts of gut and salivary gland. Ann. Trop. Med. Parasitol. 87: 303-305.
KAMWENDO S.P., MUSISI F.L., TREES A.J., MOLYNEUX D.H. 1995: Effect of haemagglutinin (lectin) inhibitory sugars in Theileria parva infection in Rhipicephalus appendiculatus. Int. J. Parasitol. 25: 29-35.

KAWABATA H., MASUZAWA T., YANAGIHARA Y. 1993: Genomic analysis of Borrelia japonica sp. nov. isolated from Ixodes ovatus in Japan. Microbiol. Immunol. 37: 843-848.

KOVÁŘ V., KOPÁČEK P., GRUBHOFFER L. 2000: Isolation and characterization of Dorin $\mathrm{M}$, a lectin from plasma of the soft tick Ornithodoros moubata. Insect Biochem. Mol. Biol. 30: 195-205.

KUHN K.H., RITTIG M., HÄUPL T., BURMESTER G.R. 1994: Haemocytes of the hard tick Ixodes ricinus express coiling phagocytosis of Borrelia burgdorferi. Dev. Comp. Immunol. 18 (Suppl. 1): S115.

KUHN K.H., UHLÍŘ J., GRUBHOFFER L. 1996: Ultrastructural localization of a sialic acid-specific hemolymph lectin in the hemocytes and other tissues of the hard tick Ixodes ricinus (Acari: Chelicerata). Parasitol. Res. 82: 215-221.

KUMARAN D., ESWARAMOORTHY S., LUFT B.J., KOIDE S., DUNN J.J., LAWSON C.L., SWAMINATHAN S. 2001: Crystal structure of outer surface protein C (OspC) from the Lyme disease spirochete, Borrelia burgdorferi. EMBO J. 20: 971-978.

KURTENBACH K., PEACEY M., RIJPKEMA S.G.T., HOODLESS A.N., NUTTALL P.A., RANDOLPH S.E. 2002: Differential transmission of the genospecies of Borrelia burgdorferi sensu lato by game bird and small rodents in England. Appl. Environ. Microbiol. 64: 11691174.

LeFLECHE, A., POSTIC D., GIRARDET K., PETER O., BARANTON G. 1997: Characterization of Borrelia lusitaniae sp. nov. by $16 \mathrm{~S}$ ribosomal DNA sequence analysis. Int. J. Syst. Bacteriol. 47: 921-925.

LEONG J.M., MORRISSEY P.E., ORTEGA-BARRIA E., PEREIRA M.E.A., COBURN J. 1995: Hemagglutination and proteoglycan binding by the Lyme disease spirochete, Borrelia burgdorferi. Infect. Immun. 63: 874-883.

LI H., DUNN J.J., LUFT B.J., LAWSON C.L. 1997: Crystal structure of Lyme disease antigen outer protein A complexed with an Fab. Proc. Natl. Acad. Sci. U.S.A. 94: 3584-3589.

LIN T., OLIVER J.H. Jr., GAO L. 2002: Genetic diversity of the outer surface protein $\mathrm{C}$ gene of southern Borrelia isolates and its possible epidemiological, clinical, and pathogenetic implications. J. Clin. Microbiol. 40: 2572-2583.

LIVEY I., GIBBS C.P., SCHUSTER R., DORNER F. 1995: Evidence for lateral transfer and recombination of OspC variation in Lyme disease. Mol. Microbiol. 18: 257-269.

MARCONI R.T., LIVERIS D., SCHWARTZ I. 1995: Identification of novel insertion elements, restriction fragments length polymorphism pattern and discontinuous $23 \mathrm{~S}$ rRNA in Lyme disease spirochetes: phylogenetic analyses of rRNA genes and their intergenic spacers in Borrelia japonica sp. nov. and genomic group 21038 (Borrelia andersonii sp. nov.) isolates. J. Clin. Microbiol. 33: $2427-$ 2434. 
MASUZAWA T. 2004: Terrestrial distribution of the Lyme borreliosis agent Borrelia burgdorferi sensu lato in East Asia. Jpn. J. Infect. Dis. 57: 229-235.

MASUZAWA T., TAKADA N., KUDEKEN M., FUKUI T., YANO Y., ISHIGURO F., KAWAMURA Y., IMAI Y., EZAKI T. 2001: Borrelia sinica sp. nov., a Lyme diseaserelated Borrelia species isolated in China. Int. J. Syst. Evol. Microbiol. 51: 1817-1824.

MÁTLOVÁ L., HALOUZKA J., JUŘICOVÁ Z., HUBÁLEK Z. 1996: Comparative experimental infection of Ixodes ricinus and Dermacentor reticulatus (Acari: Ixodidae) with Borrelia burgdorferi sensu lato. Folia Parasitol. 43: 159-160.

McDOWELL J.V., SUNG S.Z., PRICE G., MARCONI R.T. 2001: Demonstration of the genetic stability and temporal expression of select members of the Lyme disease spirochete OspF protein family during infection in mice. Infect. Immun. 69: 4831-4838.

McGOWEN M.M., VIONNET J., VANN W.F. 2001: Elongation of alpha 2,8/2,9 polysialic acid by the Escherichia coli K92. Glycobiology 11: 613-620.

NAKAJIMA Y., NATERS-YASUI A., TAYLOR D., YAMAKAWA M. 2001: Two isoforms of the arthropod defensin family from the soft tick, Ornithodoros moubata (Acari: Argasidae). Insect Biochem. Mol. Biol. 31: 747751.

NOPPA L., ÖSTBERG Y., LAVRINOVICHA M., BERGSTRÖM S. 2001: P13, an integral membrane protein of Borrelia burgdorferi, is C-terminally processed and contains surface-exposed domains. Infect. Immun. 69: 3323 3334.

OLIVER J.H. Jr., OWSLEY M.R., HUTCHESON H.J., JAMES A.M., CHEN C., IRBY W.S., DOTSON E.M., McLAIN D.K. 1993: Conspecificity of the ticks Ixodes scapularis and I. dammini (Acari: Ixodidae). J. Med. Entomol. 30: 54-63.

OYSTON P.C., PAYNE D.W., HAVARD H.L., WILLIAMSON E.D., TITBALL R.W. 1998: Production of a nontoxic site-directed mutant of Clostridium perfringens epsilon-toxin, which induces protective immunity in mice. Microbiology 144: 333-341.

PACHNER A.R. 1989: Neurologic manifestation of Lyme disease, the new "great imitator". Rev. Infect. Dis. 11: $1482-1486$

PAL U., DE SILVA A.M., MONTGOMERY R.R., FISH D., ANGUITA J., ANDERSON J.F., LOBET Y., FIKRIG E. 2000: Attachment of Borrelia burgdorferi within Ixodes scapularis mediated by outer surface protein A. J. Clin. Invest. 106: 561-569.

PAL U., LI X., WANG T., MONTGOMERY R.R., RAMAMOORTHI N., DESILVA A.M., BAO F., YANG X., PYPAERT M., PRADHAN D., KANTOR F.S., TELFORD S., ANDERSON J.F., FIKRIG E. 2004b: TROSPA, an Ixodes scapularis receptor for Borrelia burgdorferi. Cell 119: 457-468.

PAL U., YANG X., CHEN M., BOCKENSTEDT L.K., ANDERSON J.F., FLAVELL R.A., NORGARD M.V., FIKRIG E. 2004a: OspC facilitates Borrelia burgdorferi invasion of Ixodes scapularis salivary glands. J. Clin. Invest. 113: $220-230$.
PARVEEN N., CAIMANO M., RADOLF J.D., LEONG J.M. 2003: Adaptation of the Lyme disease spirochaete to the mammalian host environment results in enhanced glycosaminoglycan and host cell binding. Mol. Microbiol. 47: $1433-1444$.

PARVEEN N., LEONG J.M. 2000: Identification of a candidate glycosaminoglycan-binding adhesin of the Lyme disease spirochete Borrelia burgdorferi. Mol. Microbiol. 35: $1220-1234$.

PARVEEN N., ROBBINS D., LEONG J.M. 1999: Strain variation in glycosaminoglycan recognition influences cell-type-specific binding by Lyme disease spirochetes. Infect. Immun. 67: 1743-1749.

PERSING D.H., MATHIESEN D., PODZORSKI D., BARTHOLD A.W. 1994: Genetic stability of Borrelia burgdorferi recovered from chronically infected immunocompetent mice. Infect. Immun. 62: 3521-3527.

PICKEN R.N., CHENG Y., STRLE F., PICKEN M.M. 1996: Patient isolates of Borrelia burgdorferi sensu lato with genomic and phenotypic similarities of strain 25015. J. Infect. Dis. 174: 1112-1115.

POSTIC D., RAS N.M., LANE R.S., HENDSON M., BARANTON G. 1998: Expanded diversity among Californian Borrelia isolates and description of Borrelia bissettii sp. nov. (formerly Borrelia group DN127). J. Clin. Microbiol. 36: 3497-3504.

PROBERT W.S., KIM J.H., HÖÖK M., JOHNSON B.J.B. 2001: Mapping the ligand-binding region of Borrelia burgdorferi fibronectin-binding protein BBK32. Infect. Immun. 69: 4129-4133.

PURSER J.E., NORRIS S.J. 2000: Correlation between plasmid content and infectivity in Borrelia burgdorferi. Proc. Natl. Acad. Sci. U.S.A. 97: 13865-13870.

QIU W.G., DYKHUIZEN D.E., ACOSTA M.S., LUFT B.J. 2002: Geographic uniformity of the Lyme disease spirochete (Borrelia burgdorferi) and its shared history with tick vector (Ixodes scapularis) in the Northeastern United States. Genetics 16: 833-849.

QIU W.G., SCHUTZER S.E., BRUNO J.F., ATTIE O., XU Y., DUNN J.J., FRASER C.M., CASJENS S.R., LUFT B.J. 2004: Genetic exchange and plasmid transfers in Borrelia burgdorferi sensu stricto revealed by three-way genome comparisons and multilocus sequence typing. Proc. Natl. Acad. Sci. U.S.A. 101:14150-14155.

REGO R.O.M., HAJDUŠEK O., KOVÁŘ V., KOPÁČEK P., GRUBHOFFER L., HYPŠA V. 2005a: Molecular cloning and comparative analysis of fibrinogen-related proteins from the soft tick Ornithodoros moubata and the hard tick Ixodes ricinus. Insect Biochem. Mol. Biol. 35: 991-1000.

REGO R.O.M., KOVÁŘ V., KOPÁČEK P., WEISE C., MAN P., ŠAUMAN I., GRUBHOFFER L. 2005b: The tick plasma lectin, Dorin $\mathrm{M}$, is a fibrinogen-related molecule. Insect Biochem. Mol. Biol. (In press.)

RIBEIRO J.M.C., MATHER T.N., PIESMAN J., SPIELMAN A. 1987: Dissemination and salivary gland delivery of Lyme disease spirochetes in vector ticks (Acari, Ixodidae). J. Med. Entomol. 24: 201-205.

RICHTER D., SCHLEE D.B., ALLGOWER R., MATUSCHKA F.R. 2004: Relationships of a novel Lyme disease spirochete, Borrelia spielmani sp. nov., with its 
hosts in Central Europe. Appl. Environ. Microbiol. 70: 6414-6419.

RIJPKEMA S.G., TAZELAARD D., MOLKENBOER M., NOORDHOEK G., PLANTINGA G., SCHOULS L., SCHELLEKENS J. 1997: Detection of Borrelia afzelii, Borrelia burgdorferi sensu stricto, Borrelia garinii and group VS116 by PCR in skin biopsies of patients with erythema migrans and acrodermatitis chronica atrophicans. Clin. Microbiol. Infect. 3: 109-116.

RITTIG M.G., KUHN K.-H., DECHANT C.A., GAUCKLER A., MODOLELL M., RICCIARDI-CASTAGNOLI P., KRAUSE I.A., BURMESTER G.R. 1996: Phagocytes from both vertebrate and invertebrate species use "coiling" phagocytosis. Dev. Comp. Immunol. 20: 393-406.

RUDEL T., SCHEURERPFLUG I., MEYER T.F. 1995: Neisseria PilC protein identified as type-4 pilus tip-located adhesin. Nature 373: 357-359.

RUDENKO N., GOLOVCHENKO M., GRUBHOFFER L. 1999: Lectin-like sequences in genome of Borrelia burgdorferi. Folia Parasitol. 46: 81-90.

RUDENKO N., GOLOVCHENKO M., GRUBHOFFER L. 2001: Lectin of Borrelia burgdorferi, a new factor of spirochetal virulence? Rev. Infect. Dis. (Suppl. 3): 102-104.

RUDOLF I., HUBÁLEK Z. 2003: Effect of the salivary gland and midgut extracts from Ixodes ricinus and Dermacentor reticulatus (Acari: Ixodidae) on the growth of Borrelia garinii in vitro. Folia Parasitol. 50:159-160.

RUŽIĆ-SABLJIĆ E., LOTRIĆ-FURLAN S., MARASPIN V., CIMPERMAN J., PLETERSKI-RIGLER D., STRLE F. 2001: Analysis of Borrelia sensu lato isolated from cerebrospinal fluid. APMIS 109: 707-713.

RYFFEL K., PETER O., RUTTI B., SUARD A., DAYER E. 1999: Scored antibody reactivity determined by immunoblotting shows an association between clinical manifestations and presence of Borrelia burgdorferi sensu stricto, B. garinii, B. afzelii, and B. valaisiana in humans. J. Clin. Microbiol. 37: 4086-4092.

SAMBRI V., MASSARIA F., ARDIZZONI M., STEFANELLI C., CEVENINI R. 1993: Glycoprotein patterns in Borrelia spp. Zentralbl. Bakteriol. 279: 330-335.

SAMBRI V., STEFANELLI C., CEVENINI R. 1992: Detection of glycoproteins in Borrelia burgdorferi. Arch. Microbiol. 157: 205-208.

SCHÄFFER C., GRANINGER M., MESSNER P. 2001: Prokaryotic glycosylation. Proteomics 1: 248-261.

SCHRÖDER N.W.J., SCHOMBEL U., HEINE H., GÖBEL U.B., ZÄHRINGER U., SCHUMANN R.R. 2003: Acylated cholesteryl galactoside as a novel immunogenic motif in Borrelia burgdorferi sensu stricto. J. Biol. Chem. 278: 33645-33653.

SCHWAN T.G., PIESMAN J. 2002: Vector interaction and molecular adaptation of Lyme disease and relapsing fever spirochetes associated with transmission by ticks. Emerg. Infect. Dis. 2: 15-21.

SCHWAN T.G., PIESMAN J., GOLDE W.T., DOLAN M.N., ROSA P.A. 1995: Induction of an outer surface protein on Borrelia burgdorferi during tick feeding. Proc. Natl. Acad. Sci. U.S.A. 92: 2909-2913.

SEINOST G., DYKHUIZEN D.E., DATTWYLER R.J., GOLDE W.T., DUNN J.J., WANG I.N., WORMSER
G.P., SCHRIEFER M.E., LUFT B.J. 1999: Four clones of Borrelia burgdorferi sensu stricto cause invasive infection in humans. Infect. Immun. 67: 3518-3524.

SHOBERG R.J., THOMAS D.D. 1995: Borrelia burgdorferi vesicle production occurs via a mechanism independent of immunoglobulin $\mathrm{M}$ involvement. Infect. Immun. 63: 4857-4861.

SLAVÍČKOVÁ K. 2004: [Interaction of Ixodes ricinus tick haemocytes with Lyme borreliosis spirochetes and characterization of the glycan structures of ticks salivary glands.] MSc Thesis, University of South Bohemia, České Budějovice, Czech Republic, 51 pp. (In Czech, unpubl.)

STANEK G. 1997: Biology of Borrelia burgdorferi, risk of infection with Lyme borreliosis. In: J. Sus and O. Kahl (Eds.), Tick-borne Encephalitis and Lyme Borreliosis. Pabst Scientific Publications, Germany, pp. 230- 237.

STOITSOVA S.R., GRUBHOFFER L., NEBESÁŘOVÁ J. 2003: Exposed and hidden lectin-binding epitopes at the surface of Borrelia burgdorferi. Folia Microbiol. 48: 654658.

STRLE F., PICKEN R.N., CHENG Y., CIMPERMAN J., MARASPIN V., LOTRIC-FURLAN S., RUZICSABLJIC E., PICKEN M.M. 1997: Clinical findings for patients with Lyme borreliosis caused by Borrelia burgdorferi sensu lato with genomic and phenotypic similarities of strain 25015. Clin. Infect. Dis. 25: 273-280.

SWARTLEY J.S., MARFIN A.A., EDUPUGASTI S., LIU L.J., CIESLAK P., PERKINS B., WENGER J.D., STEPHENS D.S. 1997: Capsule switching of Neisseria meningitidis. Proc. Natl. Acad. Sci. U.S.A. 94: 271-276.

SZCZEPANSKI A., FURIE M.B., BENACH J.L., LANE B.P., FLEIT H.B. 1990: Interaction between Borrelia burgdorferi and endothelium in vitro. J. Clin. Invest. 85: $1637-1647$.

TAKADA N., MASUZAWA T., ISHIGURO F., FUJITA H., KUDEKEN M., MITANI H., FUKUNAGA M., TSUCHIYA K., YANO Y., MA X.-H. 2001: Lyme disease Borrelia spp. in ticks and rodents from northwestern China. Appl. Environ. Microbiol. 67: 5161-5165.

TENOVER F.C., ARBEIT R.D., GOERING R.V., MICKELSEN P.A., MURRAY B.E., PERSING D.H., SWAMINATHAN B. 1995: Interpreting chromosomal DNA restriction patterns produced by pulsed-field gel electrophoresis: criteria for bacterial strain typing. J. Clin. Microbiol. 33: 2233-2239.

UHLÍŘ J., GRUBHOFFER L., BORSKÝ I., DUSBÁBEK F. 1994: Antigens and glycoproteins of larvae, nymphs and adults of the tick Ixodes ricinus. Med. Vet. Entomol. 8: 141-150.

UHLÍŘ J., GRUBHOFFER L., VOLF P. 1996: Novel agglutinin in the midgut of the tick Ixodes ricinus. Folia Parasitol. 43: 233-239.

ULBRANDT N.D., CASSATT D.R., PATEL N.K., ROBERTS W.C., BACHY C.M., FAYENBAKER C.A., HANSON M.S. 2001: Conformational nature of the Borrelia burgdorferi decorin binding protein A epitopes that elicit protective antibodies 69. Infect. Immun. 69: 4799_ 4807.

VAN DAM A., KUIPER H., VOS K., WIDJOJOKUSUMO A., DE JONGH B., SPANJAARD L., RAMSELLAR A., 
KRAMER M., DANKERT J. 1993: Different genospecies of Borrelia burgdorferi are associated with distinct clinical manifestation of Lyme borreliosis. Clin. Infect. Dis. 17: 708-717.

VANCOVÁ M., NEBESÁŘOVÁ J., GRUBHOFFER L. 2005: Lectin-binding characteristics of a Lyme borreliosis spirochete Borrelia burgdorferi sensu stricto. Folia Microbiol. 50: 229-238.

VASTA G.R., MARCHALONIS J.J. 1983: Humoral recognition factors in the arthropods. The specificity of chelicerate serum lectins. Am. Zool. 23: 157-171.

WALKER A.R., FLETCHER J.D. 1990: Rhipicephalus appendiculatus feeding on rabbits and cattle: salivary-gland responses to varying host resistance. Exp. Appl. Acarol. 8: 285-290.

WANG G., VAN DAM A.P., DANKERT J. 1999: Phenotypic and genetic characterization of a novel Borrelia burgdorferi sensu lato isolate from patient with Lyme borreliosis. J. Clin. Microbiol. 37: 3025-3028.

Received 18 January 2005
WATT D.M., WALKER A.R., LAMZA K.A., AMBROSE N.C. 2001: Tick-Theileria interactions in response to immune activation of the vector. Exp. Parasitol. 97: 89-94.

WEBER K. 2001: Aspects of Lyme borreliosis in Europe. Eur. J. Clin. Microbiol. Dis. 20: 6-13.

WEBER K., PFISTER H.-W. 1993: History of Lyme borreliosis in Europe, In: K. Weber and W. Burgdorfer (Eds.), Aspects of Lyme Borreliosis. Springer-Verlag KG, Berlin, Germany, pp. 1-20.

WELKOS S.L. 1991: Plasmid-associated virulence factors of non-toxigenic (pX01-) Bacillus anthracis. Microb. Pathog. 10: 183-198.

ZEIDNER N.S., NUNCIO M.S., SCHNEIDER B.S., GERN L., PIESMAN J., BRANDAO O., FILIPE A.R. 2001: A Portuguese isolate of Borrelia lusitaniae induces disease in $\mathrm{C} 3 \mathrm{H} / \mathrm{HeN}$ mice. J. Med. Microbiol. 50: 1055-1060.

ZUNG J.L., LEWENGRUB S., RUDZINSKA M.A. 1989: Fine structural evidence for the penetration of the Lyme disease spirochete Borrelia burgdorferi through the gut and salivary tissues of Ixodes dammini. Can. J. Zool. 67: $1737-1748$.

Accepted 23 June 2005 